\title{
DEVELOPMENT AND REPRODUCTION OF Podisus distinctus (HETEROPTERA: PENTATOMIDAE) FED ON LARVA OF Bombyx mori (LEPIDOPTERA: BOMBYCIDAE)
}

\author{
LACERDA, M. C., FERREIRA, A. M. R. M., ZANUNCIO, T. V., \\ ZANUNCIO, J. C., BERNARDINO, A. S. and ESPINDULA, M. C. \\ Departamento de Biologia Animal, Universidade Federal de Viçosa, CEP 36571-000, Viçosa, MG, Brazil \\ Correspondence to: José Cola Zanuncio, Departamento de Biologia Animal, Universidade Federal de Viçosa, \\ CEP 36571-000, Viçosa, MG, Brazil, e-mail: zanuncio@ufv.br \\ Received November 25, 2002 - Accepted March 25, 2003 - Distributed May 31, 2004
}

(With 1 figure)

\begin{abstract}
Biological control has been reducing the use of chemical products against insect pests, specially predatory Pentatomidae. Species of this group can present high variations in their life cycle as a result of their diet. Thus, the objective of this research was to study nymph development and reproduction of Podisus distinctus (Stäl, 1860) (Heteroptera: Pentatomidae) fed on Bombyx mori L., 1758 (Lepidoptera: Bombycidae) larvae (T1), compared to those fed on Tenebrio molitor L., 1758 (Coleoptera: Tenebrionidae) (T2) and Musca domestica L., 1758 (Diptera: Muscidae) larvae (T3) at a temperature of $25 \pm 0.5^{\circ} \mathrm{C}$, relative humidity of $70 \pm 2 \%$, and photophase of $12 \mathrm{~h}$. Predators fed on $B$. mori showed duration of the nymph phase $(18.68 \pm 1.02)$ similar to those fed on T. molitor $(18.32 \pm 1.49)$. Pre-oviposition and oviposition periods and number of egg masses, besides eggs and nymphs per female, were higher with $B$. mori $(5.83 \pm 2.02 ; 15.00 \pm 7.40 ; 8.42 \pm 1.84 ; 296.69 \pm$ 154.75 ; and $228.55 \pm 141.04$, respectively) while longevity of males and females of P. distinctus was $25.76 \pm 16.15$ and $35.00 \pm 16.15$ days with $T$. molitor, and $20.57 \pm 13.60$ and $23.46 \pm 12.35$ days with $B$. mori, respectively.
\end{abstract}

Key words: Insecta, predator, alternative prey, Podisus distinctus.

\section{RESUMO}

\section{Desenvolvimento de Podisus distinctus (Heteroptera: Pentatomidae) alimentado com lagartas de Bombyx mori (Lepidoptera: Bombycidae)}

O controle biológico vem reduzindo o uso de produtos químicos no combate a insetos pragas, com destaque para pentatomídeos predadores, os quais apresentam variações em seu ciclo de vida, principalmente em função do regime alimentar a que são submetidos. Assim, o objetivo deste trabalho foi estudar o desenvolvimento ninfal e a produtividade de Podisus distinctus (Stäl, 1860) (Heteroptera: Pentatomidae) alimentado com larvas de Bombyx mori L., 1758 (Lepidoptera: Bombycidae) (T1), comparado com larvas de Tenebrio molitor L., 1758 (Coleoptera: Tenebrionidae) (T2) ou Musca domestica L., 1758 (Diptera: Muscidae) (T3) à temperatura de $25 \pm 0,5^{\circ} \mathrm{C}$, umidade relativa de $70 \pm 2 \%$ e fotoperíodo de $12 \mathrm{~h}$. $P$. distinctus, alimentado com $B$. mori, apresentou semelhante duração da fase ninfal $(18,68 \pm 1,02)$ em relação à alimentação com $T$. molitor $(18,32 \pm 1,49)$. Os períodos de pré-oviposição e oviposição e os números de ovos postos e de ninfas por fêmea foram maiores com B. mori $(5,83 \pm 2,02 ; 15,00 \pm 7,40$; $8,42 \pm 1,84 ; 296,69 \pm 154,75$; e 228,55 $\pm 141,04$, respectivamente), enquanto a longevidade de fêmeas e machos foi de $25,76 \pm 16,15$ e 35,00 $\pm 16,15$ dias com $T$. molitor e de 20,57 $\pm 13,60$ e 23,46 $\pm 12,35$ dias com B. mori, respectivamente.

Palavras-chave: Insecta, predador, presa alternativa, Podisus distinctus. 


\section{INTRODUCTION}

Biological control can reduce pest populations and maintain environmental balance without utilization or with lower insecticide use, which can improve life quality in different ecosystems (Symondson $e t$ al., 2002).

Pentatomidae predators feed on a large variety of insect pests (Schaeffer \& Panizzi, 2000) and are cited in Brazil as important natural enemies of eucalyptus- defoliating caterpillars (Zanuncio et al., 1994). Release of these predators against insect pests makes it necessary to study their biology and mass rearing so as to produce the highest possible number of individuals (Zanuncio et al., 2001). For this reason, these natural enemies have been reared with alternative preys such as Tenebrio molitor L., 1758 (Coleoptera: Tenebrionidae), Musca domestica L., 1758 (Diptera: Muscidae), or Bombyx mori L., 1758 (Lepidoptera: Bombycidae) (Beserra et al., 1995; Zanuncio et al., 1996/1997; Molina-Rugama et al., 1997; Nascimento et al., 1997; Jusselino Filho et al., 2001), in addition to artificial diets (Zanuncio et al., 1996; Saavedra et al., 1997; Coracini et al., 1999; De Clercq et al., 1998; and Rojas et al., 2000).

Reproduction of Podisus distinctus (Stal, 1860) (Heteroptera: Pentatomidae) has been studied with T. molitor and M. domestica (Zanuncio et al., 1998); its nymph development, with combinations of Coelomera lanio (Dalman) (Coleoptera: Chrysomelidae), B. mori, M. domestica, or T. molitor (Zanuncio et al., 1997); and its nymph weight, with $M$. domestica and T. molitor (Oliveira et al., 1999).

It is important to use alternative prey to replace natural ones with high nymph viability, and to produce heavier predator females for successful establishment under field conditions. For this reason, the objective of this research was to evaluate biological aspects of the predator $P$. distinctus fed larvae of $B$. mori, compared to those fed on larvae of T. molitor or $M$. domestica.

\section{MATERIAL AND METHODS}

This research was developed in the Laboratory of Biological Control of the Centro de Biotecnologia Aplicada à Agropecuária (BIOAGRO) of the Federal University of Viçosa (UFV) in the Municipality of Viçosa, State of Minas Gerais, Brazil. Research was done with a temperature of $25 \pm 0.5^{\circ} \mathrm{C}$, relative humidity of $70 \pm 2 \%$, and photophase of $12 \mathrm{~h}$.

Egg masses of $P$. distinctus were obtained from a mass-rearing facility of the Laboratory of Biological Control where this predator was fed larva or pupa of T. molitor. Egg masses were kept in Petri dishes $(9.0 \times 1.2 \mathrm{~cm})$ with a cotton wad soaked with distilled water until nymph emergence. Nymphs of $P$. distinctus were individualized in Petri dishes of similar size at the beginning of the second instar until emergence of adults, when they were sexed by the external appearance of their reproductive organs and conditioned in $500 \mathrm{ml}$ plastic pots. Females of $P$. distinctus were mated three days after emergence with males of similar age, and pairs of this predator were maintained in these pots until their death. Nymphs and adults of this predator received one of the alternative preys in treatments T1(larvae of B. mori); T2 (pupae of T. molitor); and T3 (larvae or pupae of $M$. domestica). These treatments had seven, seven, and five replications, each one represented by two $500 \mathrm{ml}$ pots with a pair of $P$. distinctus for treatments $\mathrm{T} 1, \mathrm{~T} 2$, and $\mathrm{T} 3$, respectively.

Survival and duration of each instar, numbers of egg masses, of eggs and nymphs per female, periods of pre-oviposition, oviposition, and posoviposition, besides longevity and weight of adults of $P$. distinctus $24 \mathrm{~h}$ after their emergence, were daily observed. Results were submitted to a variance analysis according to a complete randomized design and means were compared with the test of Duncan at $5 \%$ probability level.

\section{RESULTS}

Duration of second instar of $P$. distinctus was shorter in T2 (3.46 \pm 0.55$)$ and similar in T1 (3.90 \pm $0,37)$ and $\mathrm{T} 3(3.85 \pm 0.55)$, while third instar was longer in $\mathrm{T} 2(3.83 \pm 0.80)$ and $\mathrm{T} 1(3.65 \pm 0.66)$ than in T3 (3.40 \pm 0.73$)$. Duration of fourth and fifth instars was longer in T3 and similar in T1 and T2, while duration of the nymph phase of $P$. distinctus was shorter in T2 (18.32 \pm 1.49$)$ and T1 (18.68 \pm 1.02) than in T3 $(19.03 \pm 1.40$ days) (Table 1$)$.

Survival of $P$. distinctus was $100 \%$ in the first instar when this predator did not feed on prey, while it was $91.66 \pm 27.87 \%, 90.00 \pm 30.25 \%$, and $85.00 \pm$ 36.00 in treatments T1, T2, and T3 during second instar with similar results between treatments. 
Survival during third instar was higher in T1 (96.36 \pm $18.89)$ than in $\mathrm{T} 2(87.03 \pm 33.90)$ and $\mathrm{T} 3(80.39 \pm$ $40.09)$, while this period was similar between treatments in the fourth and fifth instars (Table 2).

Pre-oviposition, oviposition, and post-oviposition of $P$. distinctus females was $5.83 \pm 2.02,15.00 \pm 7.40$, and $7.82 \pm 6.31$ days for those fed B. mori, while these values were $10.57 \pm 3.43,11.28 \pm 9.40$, and $3.64 \pm 3.42$ days and $9.00 \pm 3.20,7.60 \pm 1.00$, and $5.50 \pm 5.80$ days for predators which received $T$. molitor or M. domestica, respectively (Table 3 ).

Higher number of egg masses (8.42 \pm 1.84$)$, eggs per female $(296.69 \pm 154.75)$ (Figure 3$)$, and nymphs per female $(228.55 \pm 141.04)$ of $P$. distinctus were obtained with $B$. mori than with
T. molitor $(4.85 \pm 1.88,141.64 \pm 98.09$, and $80.64 \pm$ $60.70)$ or $M$. domestica $(3.80 \pm 1.93,93.20 \pm 24.90$, and $34.70 \pm 18.70$ ), respectively (Table 3 ).

Longevity of $P$. distinctus males was $23.46 \pm$ $12.04,35.00 \pm 16.57$, and $19.20 \pm 8.35$ days with B. mori, T. molitor, and M. domestica, respectively with higher values in T2, while longevity of females of this predator was $20.57 \pm 14.86$ days in $\mathrm{T} 1$ and $20.30 \pm 9.33$ days in $\mathrm{T} 3$, with higher values in $\mathrm{T} 2$ (25.76 \pm 13.60 days) (Fig. 1).

With all prey, famales of $P$. distinctus were heavier than males with weight of $99.59 \pm 12.35$, $86.54 \pm 8.90$, and $73.80 \pm 7.10 \mathrm{mg}$, and $76.37 \pm$ $16.08,70.00 \pm 8.20$ and $64.80 \pm 10.96 \mathrm{mg}$ for males in $\mathrm{T} 1, \mathrm{~T} 2$, and $\mathrm{T} 3$, respectively (Fig. 1).

TABLE 1

Duration (days) (mean \pm standard error) of II, III, IV, and V instars and of the nymph phase of Podisus distinctus (Heteroptera: Pentatomidae) fed on Bombyx mori (Lepidoptera: Bombycidae) (T1), Tenebrio molitor (Coleoptera: Tenebrionidae) (T2) or Musca domestica (Diptera: Muscidae) (T3) at temperature of $25 \pm 0.5^{\circ} \mathrm{C}$, relative humidity of $70 \pm 2 \%$, and fotophase of 12 hours.

\begin{tabular}{|c|c|c|c|}
\hline \multicolumn{5}{|c|}{ Treatments } \\
\hline Instars & T1 & T2 & T3 \\
\hline II & $3.90 \pm 0,37 \mathrm{a}$ & $3.46 \pm 0.55 \mathrm{~b}$ & $3.85 \pm 0.55 \mathrm{a}$ \\
\hline III & $3.65 \pm 0.66 \mathrm{ab}$ & $3.83 \pm 0.80 \mathrm{a}$ & $3.40 \pm 0.73 \mathrm{~b}$ \\
\hline IV & $4.12 \pm 0.68 \mathrm{~b}$ & $4.17 \pm 0.70 \mathrm{~b}$ & $4.63 \pm 0.68 \mathrm{a}$ \\
\hline V & $6.00 \pm 0.55 \mathrm{ab}$ & $5.85 \pm 0.47 \mathrm{~b}$ & $6.14 \pm 0.73 \mathrm{a}$ \\
\hline Total (instars II-V) & $18.68 \pm 1.02 \mathrm{ab}$ & $18.32 \pm 1.49 \mathrm{~b}$ & $19.03 \pm 1.40 \mathrm{a}$ \\
\hline
\end{tabular}

Means followed by the same letter in a row do not differ from each other at $5 \%$ probability level by Duncan's multiple range test.

TABLE 2

Survival (\%) (mean \pm standard error) during II, III, IV, and V instars and of the nymph phase of Podisus distinctus (Heteroptera: Pentatomidae) fed Bombyx mori (Lepidoptera: Bombycidae) (T1), Tenebrio molitor (Coleoptera: Tenebrionidae) (T2), or Musca domestica (Diptera: Muscidae) (T3) at temperature of $25 \pm 0.5^{\circ} \mathrm{C}$, relative humidity of $70 \pm 2 \%$, and fotophase of 12 hours.

\begin{tabular}{|c|c|c|c|}
\hline \multicolumn{5}{|c|}{ Treatments } \\
\hline Instars & T1 & T2 & T3 \\
\hline II & $91.66 \pm 27.87 \mathrm{a}$ & $90.00 \pm 30.25 \mathrm{a}$ & $80.39 \pm 40.09 \mathrm{c}$ \\
\hline III & $96.36 \pm 18.89 \mathrm{a}$ & $87.03 \pm 33.90 \mathrm{ab}$ & $95.12 \pm 21.80 \mathrm{a}$ \\
\hline IV & $98.11 \pm 13.73 \mathrm{a}$ & $91.48 \pm 28.20 \mathrm{a}$ & $92.30 \pm 26.99 \mathrm{a}$ \\
\hline V & $96.15 \pm 19.41 \mathrm{a}$ & $100.00 \pm 0.00 \mathrm{a}$ & $60.00 \pm 09.40 \mathrm{~b}$ \\
\hline Total (instars II-V) & $83.33 \pm 27.87 \mathrm{a}$ & $71.67 \pm 45.44 \mathrm{ab}$ & $\mathrm{a}$ \\
\hline
\end{tabular}

Means followed by the same letter in a row do not differ from each other at 5\% probability level by Duncan's multiple range test. 
TABLE 3

Mean \pm standard error of biological parameters of Podisus distinctus (Heteroptera: Pentatomidae) females fed Bombyx mori (Lepidoptera: Bombycidae) (T1), Tenebrio molitor (Coleoptera: Tenebrionidae) (T2), or Musca domestica (Diptera: Muscidae) (T3) at temperature of $25 \pm 0.5^{\circ} \mathrm{C}$, relative humidity of $70 \pm 2 \%$ and fotophase of 12 hours.

\begin{tabular}{|c|r|r|c|}
\hline Parameters evaluated & T1 & T2 & T3 \\
\hline Pre-oviposition (days) & $5.83 \pm 2.02 \mathrm{c}$ & $10.57 \pm 3.43 \mathrm{a}$ & $9.00 \pm 3.20 \mathrm{~b}$ \\
\hline Oviposition (days) & $15.00 \pm 7.40 \mathrm{a}$ & $11.28 \pm 9.40 \mathrm{~b}$ & $7.60 \pm 1.00 \mathrm{c}$ \\
\hline Post-oviposition (days) & $7.82 \pm 6.31 \mathrm{a}$ & $3.64 \pm 3.42 \mathrm{c}$ & $5.50 \pm 5.80 \mathrm{~b}$ \\
\hline Egg masses (number) & $8.42 \pm 1.84 \mathrm{a}$ & $4.85 \pm 1.88 \mathrm{~b}$ & $3.80 \pm 1.93 \mathrm{c}$ \\
\hline Number of eggs & $296.69 \pm 154.75 \mathrm{a}$ & $141.64 \pm 98.09 \mathrm{~b}$ & $93.20 \pm 24.90 \mathrm{c}$ \\
\hline Nymphs/treatment (number) & $228.55 \pm 141.04 \mathrm{a}$ & $80.64 \pm 60.70 \mathrm{~b}$ & $34.70 \pm 18.70 \mathrm{c}$ \\
\hline
\end{tabular}

Means followed by the same letter in a row do not differ from each other at $5 \%$ probability level by Duncan's multiple range test.

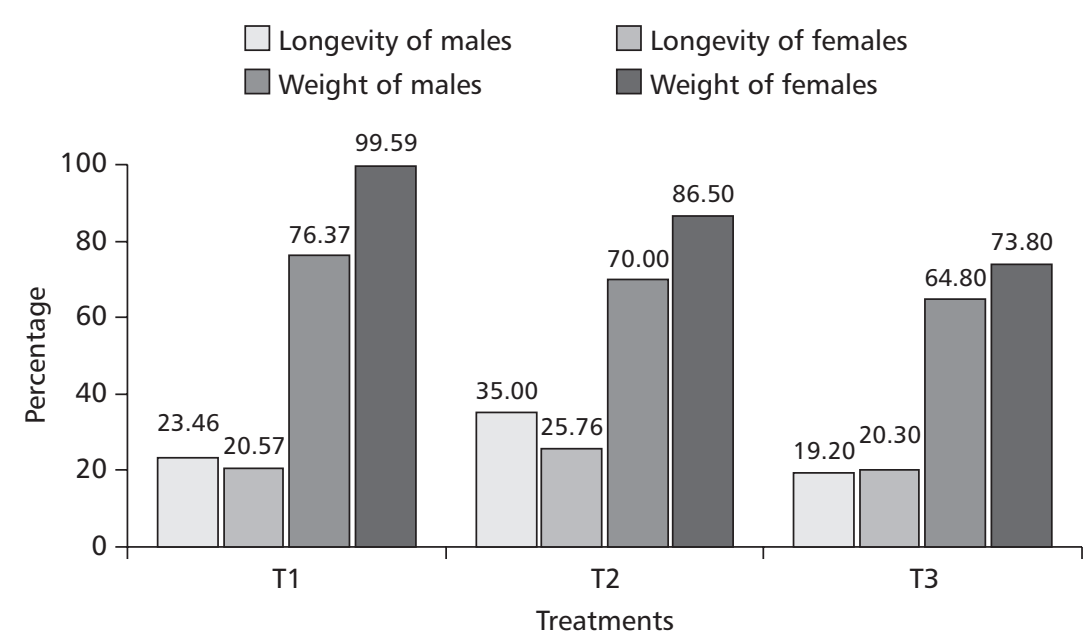

Fig. 1 - Weight and longevity of Podisus distinctus (Heteroptera: Pentatomidae) fed Bombyx mori (Lepidoptera: Bombycidae) (T1), Tenebrio molitor (Coleoptera: Tenebrionidae) (T2), or Musca domestica (Diptera: Muscidae) (T3) at temperature of 25 \pm $2^{\circ} \mathrm{C}$, relative humidity of $70 \pm 5 \%$ and photophase of 12 hours.

\section{DISCUSSION}

Duration of the nymph phase of $P$. distinctus was longer with $B$. mori than with T. molitor and $M$. domestica, and that of fourth instar was also longer with this prey, which can be related to its poor quality. This shows that $P$. distinctus needs a longer nymph period to develop its reproductive organs to develop when fed poor-quality prey such as M. domestica (Zanuncio et al., 1998). Moreover, predatory Asopinae (Heteroptera) fed with betterquality food are heavier with higher reproduction, fecundity, and number of eggs and nymphs (Evans, 1982; Zanuncio et al., 1996). Other species of this group showed similar necessities because the nymph period of $P$. distinctus was also shorter when this predator was fed B. mori. This agrees with results for the predators Podisus sculptus (Distant) (Heteroptera: Pentatomidae) (Nascimento et al., 1997) and P. nigrispinus, with longer duration of the nymph phase with $M$. domestica (Zanuncio et al., 1996/1997).

P. distinctus showed higher nymph survival in T1 $(83.33 \pm 27.87 \%)$ than in T2 $(71.67 \pm 45.44 \%)$ 
and T3 $(60.00 \pm 49.60 \%)$. This survival was higher with $T$. molitor and lower with $M$. domestica than that reported by Zanuncio et al. (1998) for this predator. This can be due to an adaptation process of $P$. distinctus after several generations in the laboratory.

The pre-oviposition period of $P$. distinctus was shorter in treatment $\mathrm{T} 1$ which shows that B. mori is a better quality prey; it also indicates that females of predators can more rapidly obtain nutrients for egg production with this prey than with T. molitor (Jusselino Filho et al., 2001). Moreover, oviposition and post-oviposition periods were longer when this predator was fed $B$. mori, further evidencing the quality of this prey, as does higher reproductive capacity of $P$. distinctus, in a manner similar to that reported for Podisus maculiventris (Say, 1831) (Heteroptera: Pentatomidae) (O'Neil \& Wiedenmann, 1990).

$P$. distinctus showed a higher number of egg masses, eggs, and nymphs per female with $B$. mori, while results for $M$. domestica and $T$. molitor were similar to those of Zanuncio et al. (1998). This shows again the better quality of $B$. mori for different species of predatory Pentatomidae because Podisus nigrolimbatus (= Brontocoris tabidus Signoret, 1852) (Zanuncio et al., 1993), Podisus sculptus Distant, 1889 (Heteroptera: Pentatomidae) (Nascimento et al., 1997), and Podisus connexivus Bergrot, 1891 (= Podisus nigrispinus Dallas, 1851) (Heteroptera: Pentatomidae) (Zanuncio et al., 1996/1997), also performed better with $B$. mori than with $T$. molitor or $M$. domestica.

Longevity of $P$. distinctus females was similar with B. mori, T. molitor, and M. domestica, suggesting that this generalist predator can maintain its longevity with different prey, and agreeing with reports of Zanuncio et al. (1997), but with reduced egg and nymph production which can limit the establishment. of $P$. distinctus in the field.

$B$. mori should be used when a higher number of individuals specially in mass-rearing programs of $P$. distinctus is necessary because this predator showed a higher number of eggs and nymphs and better nymph viability with this prey. However, the high costs of rearing $B$. mori, including the necessity of maintaining a mulberry crop and more specialized work, as well as coping with deficiency of leaves of this plant between crops, restricts the use of this prey to only when necessary in order to maintain a colony of this predator in the laboratory (Zanuncio et al., 1996/1997;
Zanuncio et al., 1998; Oliveira et al., 1999). Although it is possible to maintain $P$. distinctus with $M$. domestica larva, the use of this prey is not recommended due to consequent low egg and nymph production, as well as survival of this predator. For these reasons the colonies of $P$. distinctus should be reared with T. molitor pupae in laboratory.

Acknowledgments - To the Brazilian agencies Conselho Nacional de Desenvolvimento Científico e Tecnológico (CNPq), Coordenação de Aperfeiçoamento de Pessoal de Nível Superior (CAPES) and Fundação de Amparo à Pesquisa do Estado de Minas Gerais (FAPEMIG).

\section{REFERENCES}

BESERRA, E. B., ZANUNCIO, T. V., ZANUNCIO, J. C. \& SANTOS, G. P., 1995, Desenvolvimento de Supputius cincticeps (Heteroptera, Pentatomidae) alimentado com larvas de Zophobas confusa, Tenebrio molitor (Coleoptera: Tenebrionidae) e Musca domestica (Diptera: Muscidae). Rev. Brasil. Zool., 12: 725-733.

CORACINI, M. D. A., VILELA, E. F., JUNIOR, P. M., ZANUNCIO, J. C. \& FURTADO, M. F., 1999, Localização e aceitação de dieta artificial contendo feromônio sexual pelo predador Podisus nigrispinus (Dallas) (Heteroptera: Pentatomidae). An. Soc. Entomol. Bras., 28: 687-693.

DE CLERCQ, P., MERLEVEDE, F. \& TIRRY, L., 1998, Unnatural prey and artificial diets for rearing Podisus maculiventris (Heteroptera: Pentatomidae). Biol. Cont., 12: 137-142.

EVANS, E. W., 1982, Consequences of body size for fecundity in the predatory stinkbug, Podisus maculiventris (Hemiptera: Pentatomidae). Ann. Entomol. Soc. Amer., 75: 418-420.

JUSSELINO FILHO, P., ZANUNCIO, J. C., GUEDES, R. N. C. \& FRAGOSO, D. B., 2001, Desarollo y reproducción del predador Brontocoris tabidus (Heteroptera: Pentatomidae) alimentado com larvas de Tenebrio molitor (Coleoptera: Tenebrionidae). Rev. Colomb. Entomol., 1/2: 45-48.

MOLINA-RUGAMA, A. J., ZANUNCIO, J. C., TORRES, J. B. \& ZANUNCIO, T. V., 1997, Longevidad y fecundidad de Podisus nigrispinus (Heteroptera: Pentatomidae) alimentado com Musca domestica (Diptera: Muscidae) y frijol. Rev. Biol. Trop., 45: 1125-1130.

NASCIMENTO, E. C., ZANUNCIO, J. C., PICANÇO, M. C. \& ZANUNCIO, T. V., 1997, Desenvolvimento de Podisus sculptus Distant, 1889 (Heteroptera: Pentatomidae) em Bombyx mori (Lepidoptera: Bombycidae) e Tenebrio molitor (Coleoptera: Tenebrionidae). Rev. Brasil. Biol., 57: 195201 .

O'NEIL, R. J. \& WIEDENMANN, R. N., 1990, Body weight of Podisus maculiventris (Say) under various feeding regimens. Can. Entomol., 122: 285-294.

OLIVEIRA, H. N., ZANUNCIO, J. C., SOSSAI, M. F. \& PRATISSOLI, D., 1999, Body weight increment of Podisus distinctus (Stal) (Heteroptera: Pentatomidae) fed on Tenebrio molitor L. (Coleoptera: Tenebrionidae) or Musca domestica L. (Diptera: Muscidae). Brenesia, 51: 77-83. 
ROJAS, M. G., MORALES-RAMOS, J. A. \& KING, E. G., 2000, Two meridict diets for Perillus bioculatus (Heteroptera: Pentatomidae), a predador of Leptinotarsa decemlineata (Coleoptera: Chrysomelidae). Biol. Cont., 17: 92.99.

SAAVEDRA, J. L. D., ZANUNCIO, J. C., ZANUNCIO, T. V. \& GUEDES, R. N. C., 1997, Prey capture ability of Podisus nigrispinus (Dallas) (Heteroptera: Pentatomidae) reared for successive generations on meridic diets. Journ. Appl. Entom., 121: $327-330$.

SCHAEFFER, C. W. \& PANIZZI, A. R., 2000, Heteroptera of economic importance. CRC Press, New York.

SYMONDSON, W. O. C., SUNDERLAND, K. D. \& GREENSTONE, M. H., 2002, Can generalist predators be effective biocontrol agents? Ann. Rev. Entomol., 47: 561594.

ZANUNCIO, T. V., ZANUNCIO, J. C., BATALHA, V. C. \& SANTOS, G. P., 1993, Efeito da alimentação com lagartas de Bombyx mori e larvas de Musca domestica no desenvolvimento de Podisus nigrolimbatus (Hemiptera, Pentatomidae). Rev. Brasil. Entomol., 37: 273.

ZANUNCIO, J. C., ALVES, J. B., ZANUNCIO, T. V. \& GARCIA, J. F., 1994, Hemipterous predators of Eucalypt desfoliator caterpillars. For. Ecol. Manage., 65: 65-73.
ZANUNCIO, J. C., SAAVEDRA, J. L., ZANUNCIO, T. V. \& SANTOS, G. P., 1996, Desarollo y reproducción de Supputius cincticeps (Heteroptera: Pentatomidae) en dieta artificial por dos generaciones. Int. Jour. Trop. Biol. Cons., 44-45: $247-251$.

ZANUNCIO, J. C., SAAVEDRA, J. L. D., ZANUNCIO, T. V. \& SANTOS, G. P., 1996/1997, Incremento en el peso de ninfas y adultos de Podisus nigrispinus (Heteroptera: Pentatomidae) alimentados com dos tipos de larvas. Int. Jour. Trop. Biol. Cons., 45: 241-245.

ZANUNCIO, J. C., TORRES, J. B., BERNARDO, D. L. \& DE CLERCQ, P., 1997, Effects of prey switching on nymphal development of four species of predatory stinkbugs. Med. Fac. Landbouww. Univ. Gent., 62: 483-490.

ZANUNCIO, T. V., TORRES, J. B., ZANUNCIO, J. C. \& SANTOS, G. P., 1998, Ciclo de vida e reprodução de Podisus distinctus (Stal) (Heteroptera, Pentatomidae) alimentado com dois tipos de presas. Rev. Bras. Entomol., 41: 335-337.

ZANUNCIO, J. C., MOLINA-RUGAMA, A. J., SERRÃO, J. E. \& PRATISSOLI, D., 2001, Nymphal development and reproduction of Podisus nigrispinus (Heteroptera: Pentatomidae) fed with combinations of Tenebrio molitor (Coleoptera: Tenebrionidae) pupae and Musca domestica (Diptera: Muscidae) larvae. Bioc. Sci. Tech., 11: 331-337. 